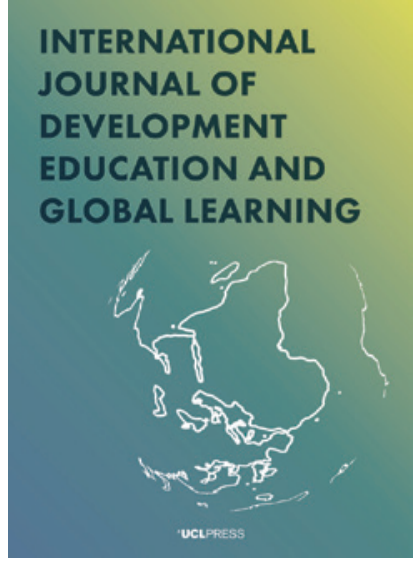

${ }^{\star}$ UCLPRESS

\title{
INTERNATIONAL JOURNAL OF DEVELOPMENT EDUCATION AND GLOBAL LEARNING
}

e-ISSN: $1756-5278$

Journal homepage:

https://www.uclpress.co.uk/pages/international-journalof-development-education-and-global-learning

\section{An exploration of how teachers' attitudes to global learning can be used to inform primary science education}

\section{Amy Strachan (D)}

\section{How to cite this article}

Strachan, A. (2020) 'An exploration of how teachers' attitudes to global learning can be used to inform primary science education'. International Journal of Development Education and Global Learning, 12 (2), 121-32. https://doi.org/10.14324/IJDEGL.12.2.04

Submission date: 30 March 2020

Acceptance date: 22 June 2020

Publication date: 15 December 2020

\section{Peer review}

This article has been peer-reviewed through the journal's standard double-blind peer review, where both the reviewers and authors are anonymized during review.

\section{Copyright}

(C) 2020 Strachan. This is an open-access article distributed under the terms of the Creative Commons Attribution Licence (CC BY) 4.0 https://creativecommons.org/licenses/by/4.0/, which permits unrestricted use, distribution and reproduction in any medium, provided the original author and source are credited.

\section{Open access}

The International Journal of Development Education and Global Learning is a peer-reviewed open-access journal. 


\title{
An exploration of how teachers' attitudes to global learning can be used to inform primary science education
}

\author{
Amy Strachan* - St Mary's University, Twickenham, UK
}

\begin{abstract}
This article contends that in England, where the status of science as a core subject has been weakened due to a focus on high-stakes accountability testing, a global learning approach reignites science as a subject that can nurture active global citizens. It argues that teacher knowledge and teachers' personal and professional commitment to global issues can inform a more relevant and purposeful primary science education, empowering both them and those they teach to become agents of change. It suggests that by exploring Sustainable Development Goals (SDGs) and their relation to the primary science curriculum in England, as well as developing a series of pedagogical strategies in line with global learning, teaching and learning in primary science can become more engaging and purposeful beyond fulfilling an assessment framework. A mixed-methods research design was used to explore and inform the Global Learning in Primary Science (GLPS) project. The findings suggest that while practitioners shared a positive attitude to a global learning approach, without being explicitly indicated in curriculum policy, its integration will continue to be left to chance. This global learning approach provides an opportunity for primary science education to become valued as dynamic process which supports sustainable development rather than remaining a static body of knowledge.
\end{abstract}

Keywords: global learning, professional development, Sustainable Development Goals, agents of change, beliefs, primary science education, policy

\section{Introduction}

The United Nations 2030 agenda for sustainable development emphasizes the importance of collaborative action to transform our world (UN, 2015). It is widely agreed that education is central to facilitating change (UNECE, 2016), and exploring Sustainable Development Goal (SDG) 4.7 focuses on the importance of learners acquiring the knowledge and skills they need to promote sustainable development (UN, 2015). The United Nations global indicator framework for sustainable development places a focus on integrating global citizenship education across all settings (UN, 2017), but it now needs to be considered how this can be operationalized.

With a specific focus on primary science education, this article argues that the promotion of teacher knowledge and professional and personal commitment to sustainable development can inform a more relevant and purposeful science education, empowering teachers and children to become agents of change. Although there is a large body of research focusing on whole school approaches to global learning (Hunt and King, 2015), this study suggests that there is an opportunity for teaching and learning in primary science to move beyond fulfilling an assessment 
framework to become more engaging and purposeful. This could be achieved by explicitly highlighting SDGs and their relation to the primary science curriculum and developing a series of pedagogical strategies in line with global learning (UNESCO, 2014). Biannual national testing in primary science indicates that only 21 per cent of 11-year-olds were performing sufficiently well in science (Standards and Testing Agency, 2019). Further to this, a report that surveyed over 1,010 teachers indicated that 58 per cent of primary classes in England were not receiving at least two hours of science per week, with 12 per cent of schools surveyed not delivering weekly science lessons (Leonardi et al., 2017). This study, therefore, explores how a global learning approach can not only support the operationalization of SDGs, but can simultaneously raise the quality of primary science, a subject which currently has a reduced status in English primary schools (Leonardi et al., 2017).

\section{Do practitioners have a positive attitude towards a global learning approach to primary science education?}

This research considers how, and if, there is an opportunity for practitioners to use global learning - defined as an approach towards learning that equips young people to make a positive contribution to a globalized world (Bourn, 2015) - to underpin a valuable and purposeful primary science education. A particular focus of global learning is to develop pedagogical approaches which support a global awareness and understanding of interdependence (Bourn, 2016). The objective of the Global Learning in Primary Science (GLPS) project was to consider this pedagogical approach specifically in relation to primary science, exploring how to engage and support teachers in the delivery of a science education that is relevant to future citizens and contributes to improved teacher engagement and subsequent educational quality.

A synthesis of the research identifies that high-quality professional development must acknowledge the importance of teachers' own needs and the professional attitudes and behaviours that underpin their knowledge and skills, and the value of reflective professional activities (Cordingley, 2015). This research also emphasizes the importance of teachers' subject and pedagogical content knowledge (PCK), as established by Shulman (1986), which enables practitioners to have autonomy in the decisions they make in implementing the science curriculum. The study was therefore underpinned by an understanding that a new pedagogical approach must consider and align with practitioner attitudes in order to be successful. The approach outlined in this article explores how these professional development characteristics have the potential to develop subject-specific pedagogy to promote sustainable development, with the support of an explicit indication in policy framework.

\section{The Global Learning in Primary Science project}

As highlighted in the introduction, previous research on global learning has mainly focused on a whole school approach (Bourn, 2016). However, a few studies have focused specifically on the subject-level aspects of its implementation. The GLPS Project explored four aspects: aligning individual and school attitudes about the purpose of primary science education to the values of global learning; identifying links between SDGs and the primary science curriculum (DfE, 2013); promoting a community of practice (Lave and Wenger, 1991) through which primary science practitioners collaborate and share ideas; and promoting a range of strategies and resources that advance a global learning approach to primary science, as Table 1 shows. 
Table 1: A framework for integrating SDGs and global learning into programmes of study (Source: Authors, 2020)

\begin{tabular}{ll}
\hline Programme of study - GLPS planning framework \\
\hline Year group: & Programme of study: \\
Wider purpose/ & Global competencies/ \\
global context/ & attitudes developed: \\
SDG lens: & Meaningful scientific \\
Pedagogical strategies & enquiries (progression of \\
(P4C, critical thinking, & working scientifically skills): \\
OSED, etc.): &
\end{tabular}

Child-led enquiries and application of learning:

Global competencies: Understanding different perspectives, collective responsibilities, collaboration and communication, awareness of global issues, problem-solving.

The project incorporated the development of pedagogical strategies aligned with global learning pedagogical approaches: Philosophy for Children (Lipman et al., 1980), critical thinking and Open Spaces for Dialogue and Enquiry (OSDE) (Andreotti, 2011). The strategies highlighted also aimed to allow children to see how their science learning was personally relevant and drew upon different perspectives (inspired by the transformative learning approach developed by Mezirow (2000), which is used in higher education). The 2030 SDGs provided overarching themes for applying science knowledge and skills to the real world and enabled teachers (and children) to engage with these fundamental global issues. A global learning approach to primary science was developed through an iterative process. After each workshop, responses and reflections from teachers were fed back into further developing the workshops to ensure that they aligned with the underpinning theoretical framework and supported teachers pragmatically.

Research by Pajares (1992) identified the influence of teachers' beliefs on classroom instruction, suggesting that practitioners' engagement with a new pedagogical approach required finding a shared set of values. Examining the relationship between teachers' pedagogical beliefs and science practices with a global learning approach was conducted to support its adoption. Engagement at all levels - from consultants, senior leaders, leaders of science and teachers - was considered fundamental in supporting the implementation of a global learning approach to primary science. As a result, the attitudes and engagement of all stakeholders in the approach were explored.

Continuing professional development (CPD) is considered an important aspect of supporting change in the way a subject is delivered (Guskey, 2000; Goodall et al., 2005). Attention to the role of teacher agency within research on teacher professional development has grown significantly during the last decade (Imants and Van der Wal, 2020). An awareness of the roles of teachers as agents of change, as well as shining a light on the importance of professional identity in sustained change (Priestley et al., 2012), were significant aspects of this study. In specifically considering the successful implementation of global learning in primary science education, a framework was required to analyse how successfully professional learning supported change. Subsequently, a model developed by Priestley et al. (2015) was selected to analyse the impact of a global learning approach to the GLPS Project. It focused on three dimensions: iterational (the developments of an individual's professional knowledge, beliefs and values), projective (interpreting 
the perceived approach within their own teaching) and practical-evaluative (the confidence to make decisions for wider change).

\section{Research methods and analytical framework}

The research used an embedded mixed-methods research design (Creswell and Plano Clark, 2011), with a quantitative attitudinal survey and semi-structured interviews that explored and informed the use of a professional development framework to support schools, teachers and pre-service teachers in the integration of a global learning approach to science education. Professional development sessions along with the attitudinal survey were used to measure attitudes towards global learning in primary science with the aim of supporting practitioners to connect core curriculum objectives to global dimensions, SDGs and global learning pedagogical strategies.

The attitudinal survey constructed by Bamber et al. (2013) was used to compare the attitudes of different groups towards global learning in primary science education (see Table 2). These included 30 headteachers, 30 primary science advisers, 30 leaders of primary science, 30 primary school teachers and 30 pre-service primary teachers (150 respondents in total) through purposive sampling of voluntary respondents from the network of schools partnered with my university (St Mary's University, Twickenham). This provided the respondents with a score for the inventory that indicated their overall attitudes regarding, in this case, global learning in primary science education. The attitudinal values were ascertained by calculating the mean of all items ticked (see Table 2 for weightings of each item). The sample groups were then analysed and compared in order to identify any initial patterns in attitudes towards global learning in primary science.

Table 2: The attitudinal survey for the Global Learning in Primary Science Project (adapted from Bamber et al., 2013)

\begin{tabular}{|c|c|}
\hline Weighting & Statement \\
\hline 6.31 & $\begin{array}{l}\text { I think it's really important for young people to know what's going on in the } \\
\text { world }\end{array}$ \\
\hline 1.00 & $\begin{array}{l}\text { Having a global dimension to my science lessons is totally pointless and would } \\
\text { detract from my important learning }\end{array}$ \\
\hline 6.85 & $\begin{array}{l}\text { Global learning is absolutely essential for the development of myself and those } \\
\text { I teach }\end{array}$ \\
\hline 2.00 & $\begin{array}{l}\text { Global learning is a low-priority issue on the scale of what is important in my life } \\
\text { and my work }\end{array}$ \\
\hline 3.08 & $\begin{array}{l}\text { While creative thinking is important there are things in science which take a } \\
\text { higher priority }\end{array}$ \\
\hline 5.69 & Global learning adds to pupil learning of science \\
\hline 4.00 & $\begin{array}{l}\text { I think global learning is significant but honestly don't know if it is more or less } \\
\text { important than mathematics or English }\end{array}$ \\
\hline 5.38 & Young people should be aware of different perspectives in science \\
\hline 2.08 & Global learning is too complex to engage with \\
\hline 2.46 & $\begin{array}{l}\text { Incorporating global learning in science is beyond the role/scope of being a } \\
\text { teacher }\end{array}$ \\
\hline 1.00 & I hate the whole idea of teaching about global learning in science \\
\hline 4.23 & $\begin{array}{l}\text { While global perspectives in learning could be important, the concept may } \\
\text { need further clarification to be usefully applied to the science curriculum }\end{array}$ \\
\hline 6.85 & I am very passionate about global learning \\
\hline 5.15 & $\begin{array}{l}\text { Global learning is possibly one way to promote critical thinking in science } \\
\text { lessons }\end{array}$ \\
\hline
\end{tabular}


Semi-structured interviews were then conducted with a sample of each group $(n=5)$ to explore the challenges and opportunities around integrating a global learning approach into the subject area. Finally, three case studies were used to explore the impact of global learning professional development and planning tools on primary science teaching and learning, using the professional agency analysis model described above.

Ethical considerations for the study included: participation in the study was voluntary and the aim of the study was explained to all participants; participants and schools were assured of their anonymity in the presentation of the findings; and ethical clearance for the study was obtained in line with the British Educational Research Association's (BERA) ethics guidelines.

\section{Findings and discussion}

A total of 150 individuals (30 in each group) participated in the study on integrating a global learning approach into primary science. Participants completed the attitudinal survey before participating in the GLPS workshops. The teachers participated in a series of activities that supported them in mapping the SDGs and pedagogical strategies onto their science schemes of work, situating activities within the framework of the English National Curriculum for Science (DfE, 2013).

As indicated in Table 3, all sample groups - students, teachers and advisers were generally positive in their attitude towards the study (a score of 4 was a neutral stance, so anything above that is deemed as positive). There was little variation in the mean inventory score for each group: pre-service teacher (5.67), teachers (5.574) and primary science advisers (5.212). It was notable that most students started the programme with a positive attitude towards the importance of global learning, with 100 per cent agreeing with the statement 'I think it's really important for young people to know what's going on in the world'. Similarly, no students agreed with the negatively framed statement, 'I hate the whole idea of teaching about global learning in science' and no student agreed with 'Having a global dimension to my science is totally pointless and would detract from my important learning'. This was noteworthy, given that previous research related to delivering development education found that negative beliefs and attitudes 'have a disproportionately strong effect on teachers' motivation and confidence' (Bracken and Bryan, 2010: 36). Although only slight, it was evident that the advisers' attitudes to global learning in primary science were less positive than those of the other groups. During semi-structured interviews, it was evident that this group was most concerned by the underpinning subject knowledge that would support the effective implementation of a global learning approach. This group was also concerned about the time constraints in delivering the objectives set out in the programmes of study in England (DfE, 2013).

Although all items in the survey were explored as part of the thesis (see Table 3), Table 4 explores the responses to three specific statements regarding attitudes and motivation towards global learning in primary science. One relates to the priority given by individual teachers to give global learning in their teaching and the other is about their enthusiasm for this educational approach. These were: S3 'Global learning is absolutely essential for the development of myself and those I teach' which was weighted 6.85 and indicates the importance attached to global learning by different stakeholders, and S13 'I am passionate about global learning in primary science' which was weighted 6.85 and indicates the motivation of professionals to use global learning. The other item explored is S12 'While global perspectives in learning could 


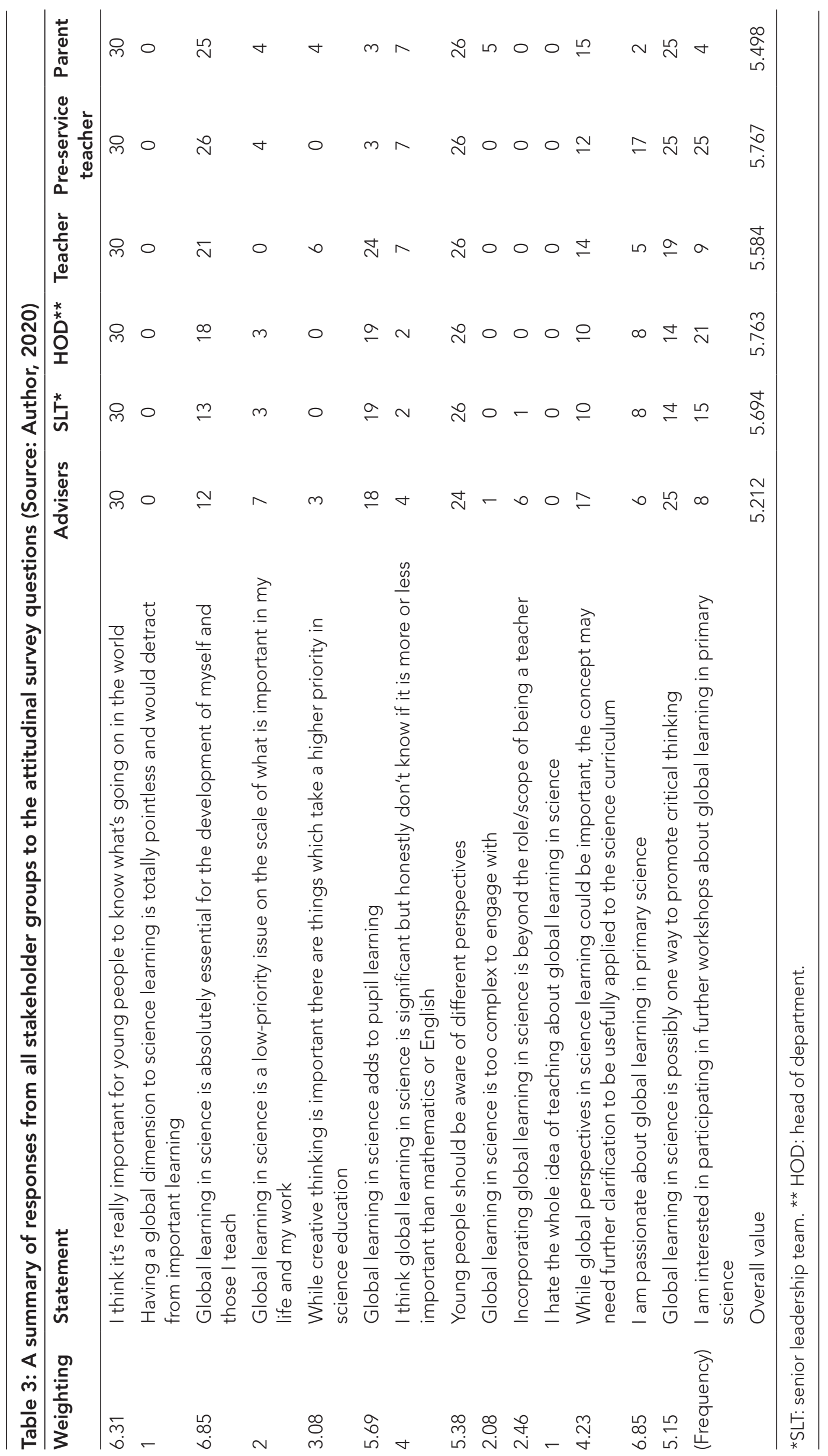


Table 4: Responses from the GLPS attitudinal survey (Source: Author, 2020)

\begin{tabular}{lcccc}
\hline Sample group & $\begin{array}{c}\text { Average } \\
\text { inventory } \\
\text { score }\end{array}$ & $\begin{array}{c}\text { Percentage } \\
\text { agreeing with } \\
\text { 'Global learning } \\
\text { is absolutely } \\
\text { essential for the } \\
\text { development } \\
\text { of myself and } \\
\text { those I teach' } \\
\text { (S3) }\end{array}$ & $\begin{array}{c}\text { Percentage } \\
\text { agreeing } \\
\text { with 'I am } \\
\text { passionate } \\
\text { about global } \\
\text { learning } \\
\text { in primary } \\
\text { science' (S13) }\end{array}$ & $\begin{array}{c}\text { Percentage agreeing } \\
\text { with 'While global } \\
\text { perspectives in } \\
\text { learning could be } \\
\text { important, the } \\
\text { concept may need } \\
\text { further clarification } \\
\text { to be usefully applied } \\
\text { to the science } \\
\text { curriculum' (S12) }\end{array}$ \\
\hline $\begin{array}{l}\text { Pre-service teachers } \\
\text { Teachers }\end{array}$ & 5.767 & $83(26)$ & $57(17)$ & $40(12)$ \\
$\begin{array}{l}\text { Primary science } \\
\text { advisers }\end{array}$ & 5.574 & $70(21)$ & $17(5)$ & $47(14)$ \\
$\begin{array}{l}\text { School senior } \\
\text { leadership team }\end{array}$ & 5.212 & $57(12)$ & $20(6)$ & $57(17)$ \\
$\begin{array}{l}\text { Leaders of primary } \\
\text { science in schools }\end{array}$ & 5.694 & $43(13)$ & $27(8)$ & $33(10)$ \\
\hline
\end{tabular}

be important, the concept may need further clarification to be usefully applied to the science curriculum', which indicates the importance of the need for further support and professional development for teachers.

Of the pre-service teachers, 83 per cent agreed with S3 'Global learning is absolutely essential for the development of myself and those I teach' at the start of their programme of study, compared with only 57 per cent of consultants. A large proportion of pre-service teachers therefore considered global learning to be important, highlighting an initial motivation to operationalize this into their subjectspecific pedagogy training. A smaller proportion of pre-service teachers (53 per cent) agreed with S13 'I am passionate about global learning'. As these attitudes can impact on decisions regarding pedagogical practice, it is important to highlight this split perspective: how to support pre-service teachers in exploring the purpose of primary science education and emphasizing the importance of global learning are both fundamental to the integration of a global learning pedagogical approach in the classroom. Pointedly, this figure decreased for both teachers and consultants. Again, as verified in the semi-structured interviews, this highlighted the influence of highstakes testing and national accountability in terms of covering the National Curriculum as a priority in the profession.

A survey conducted by the Wellcome Trust (Leonardi et al., 2019) to explore the state of primary science in the UK identified that only 52 per cent of leaders in primary science had undertaken external continued professional development (CPD) to support leadership and the development of science in their schools. Even fewer teachers undertook any external CPD and instead were supported by the subject leader (Leonardi et al., 2019). Following this, if stakeholders do not have an initial motivation to explore a particular approach, they are less likely to engage in related professional development. This was supported by semi-structured interviews which identified that teachers and consultants were less likely to want to pursue further training (see Table 5), due to other priorities such as English and mathematics. Although not decisive, this research suggests that policy frameworks and Initial Teacher Training programmes 
Table 5: A comparison of attitudes to a global learning approach to primary science and the desire to pursue further related professional learning (Source: Author, 2020)

\begin{tabular}{lccc}
\hline Stakeholder group & $\begin{array}{c}\text { Attitudinal } \\
\text { value }\end{array}$ & $\begin{array}{c}\text { Percentage of respondents } \\
\text { from attitudinal survey who } \\
\text { identified they would like } \\
\text { further information about the } \\
\text { approach }\end{array}$ & $\begin{array}{c}\text { Percentage of } \\
\text { respondents from } \\
\text { semi-structured } \\
\text { interviews }\end{array}$ \\
\hline Pre-service teachers & 5.767 & $83(25)$ & $100(5)$ \\
Teacher & 5.574 & $30(9)$ & $60(3)$ \\
Primary science advisers & 5.212 & $27(8)$ & $60(3)$ \\
$\begin{array}{l}\text { School senior leadership } \\
\text { team }\end{array}$ & 5.694 & $50(15)$ & $40(2)$ \\
Leaders of primary & 5.763 & $70(21)$ & $60(3)$ \\
science in schools & & & \\
\hline
\end{tabular}

have a responsibility to ensure that a global learning approach to science education is operationalized, rather than left to chance, especially as it is in competition with policy frameworks and accountability measures.

Bamber et al. (2013) include statements that refer to ideas underpinning this educative approach. This study adapted these statements to focus on an approach to science education. The statement 'While global perspectives in learning could be important, the concept may need further clarification to be usefully applied to the science curriculum' indicated whether individuals felt a need for further support and development. Significantly, as identified in Table 4, only 40 per cent of pre-service teachers agreed, compared with 57 per cent of advisers. Although it is important to support pre-service teachers with related knowledge and strategies, developing and challenging the attitudes of those advising the development of primary science education will be essential for the success of this approach. Only when advisers see global learning as a priority, due to it being made explicit in curriculum policy, will they ensure that they invest in related professional development.

Table 6 draws on the clear relationship between the aspects of the global learning approach to primary science established as influencing change and the dimensions of teacher agency, set out by Priestley et al. (2015) in their 'ecological approach' to teacher agency, in which agency is understood as a growing phenomenon dependent on the interplay between teachers' contexts and their individual capacities. Semi-structured interviews with case study schools suggested that teachers' agency was dependent on their own influence as well as the culture of the school. For example, those who were subject leaders and members of the senior leadership team were more likely to be able to influence and change the approach used by the school. Developing a shared vision which incorporated the global learning approach was motivational and enabled the establishment of a community of practice within a school, which allowed practitioners to share their passion for global issues (such as climate change and sustainable resources) and learn how incorporate them more effectively into science learning.

The findings demonstrated that it was important to trial resources as this could have a potential influence on teachers' agency. Sharing online platforms was useful, providing respondents with collaborative time in which to consider the integration of science resources with a global lens and approaches. This not only enabled them to 


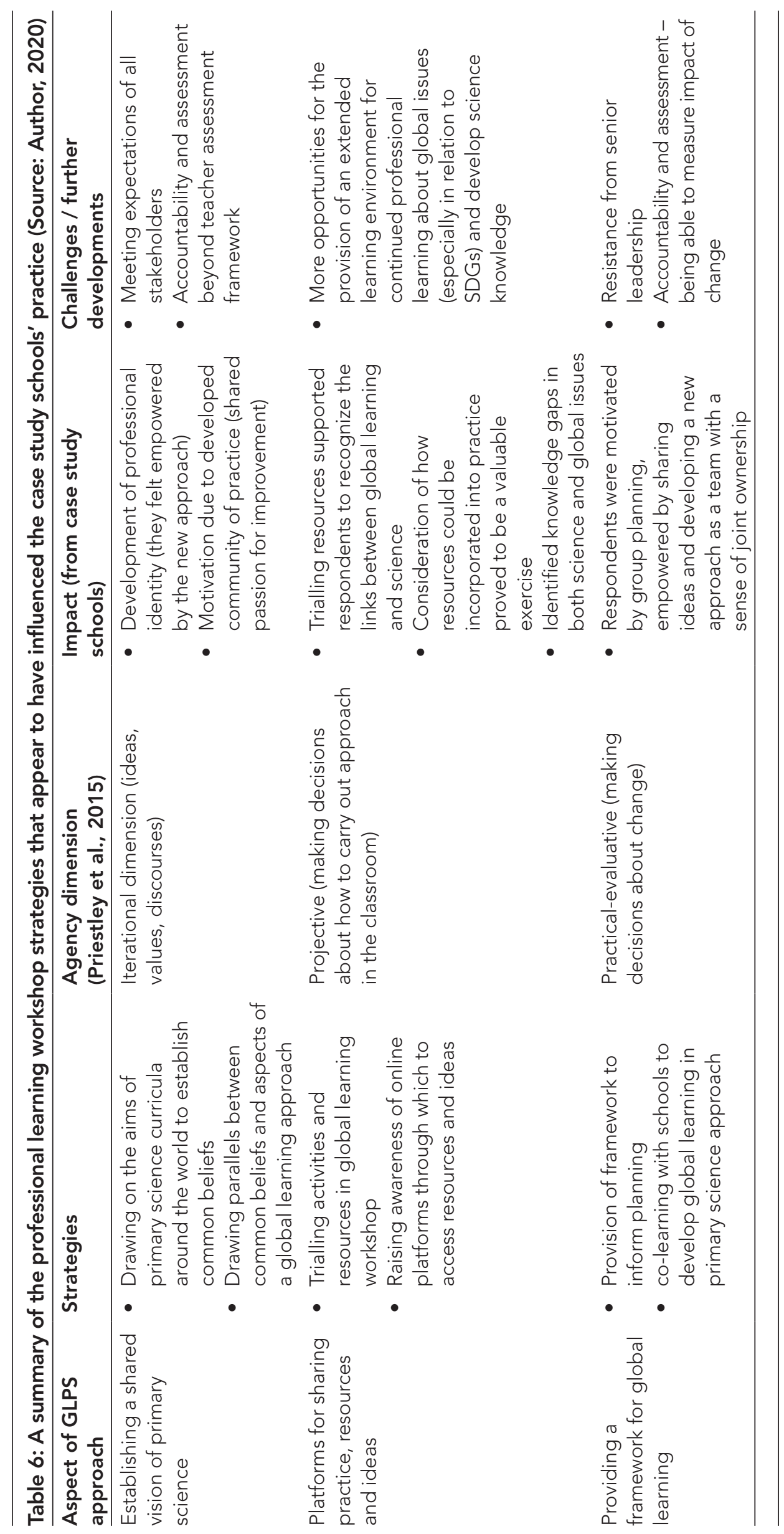


see the added value in their science lessons, but also aided the development of their own science and global learning knowledge and understanding.

The results further underlined that while all stakeholders have positive attitudes towards global learning as an approach to primary science education, all groups highlighted a desire to invest in their own understanding of SDGs and a global learning approach in order to apply it to primary science education. The study also showed that those groups that had more influence over pedagogical change such as advisers and head teachers, while still positive about a global learning approach, highlighted that confidence in foundation subject knowledge and skills remained a priority in their roles. Without an explicit mention of SDGs and global learning in subject-specific curriculum policy, discourse and professional learning in this field may be left to chance.

Finally, the structural dimension of the school was fundamental to teacher agency and the successful implementation of the global learning approach. As Priestley et al. (2015) recognize, beyond global learning workshops, decision-making was dependent on the priorities and culture of the school. Although collaborative planning empowered practitioners and joint ownership was seen as important, support and collaboration with senior leadership was seen as the most important motivating factor. Senior leadership and subject leader support for integrating global learning into a school's science planning framework was important for the sustainability of the approach.

\section{Implications}

Training pre-service primary teachers in the knowledge, skills and strategies that are required to adopt a global learning pedagogical approach to teaching primary science has the potential to promote greater engagement in and autonomy around the primary science curriculum, ensuring that it is meaningful to our future global citizens. Not only does science provide a vehicle through which to engage teachers and pupils with the 2030 SDGs, but it provides a foundation for authentic twenty-first-century learning. If we enable teachers to see the value of science education in helping younger generations to become informed, participatory citizens, willing to make responsible choices about their lifestyles in the modern world, frameworks such as global learning in primary science have the potential to raise the profile and quality of primary science education.

So far trainee teachers have responded positively to a global learning approach to primary science. However, what became evident as the project unfolded was the complexity of issues related to the SDGs. Not only were a range of pedagogical strategies needed to carry out meaningful global learning in primary science, but a greater knowledge of the SDGs was necessary for effective planning and delivery. The opportunity to collaborate and listen to different perspectives; to reflect on new discoveries; to raise personally meaningful, investigable questions; to develop scientific literacy and to make responsible choices were all evidenced in the case study schools, but teachers highlighted the need for guidance and resources to support them in linking global issues. This will be especially challenging in cases where pre-teachers' own subject knowledge in science is weak (Leonardi et al., 2017). Consequently, developing a confident approach needs to be nurtured and supported over time and revisited throughout Initial Teacher Training programmes and subsequent professional development.

The initial workshops integrating global learning into primary science were received with similar engagement and enthusiasm from local schools. It was evident, however, that introducing a new pedagogical approach to established teachers, despite aligning it with their attitudes to primary science, requires further consideration. The need to ensure the support of senior leadership and subject leadership was visible, as 
was the collaboration of teachers in reflecting on and redesigning science programmes of study to take a global learning approach (in line with the professional agency model).

Further research is therefore important, in order to consider how professional development models can be implemented to challenge established teachers' belief systems and to encourage them to take the leap in their already established approach to primary science teaching and learning to ensure it is fit for our future global citizens. Global learning approaches tend to promote a transformative approach to teaching and learning, and this presents major challenges to teacher training and education of teachers which focus on delivering a prescribed curriculum based on national accountability. Policymakers outside of education can have a major influence in determining the practices of global learning within teacher education. Continued research, therefore, is needed to highlight the impact of global learning and SDGs as a driving force of a purposeful and relevant science curriculum.

\section{Contribution to knowledge}

Findings showed that there is a consistency between respondents' beliefs about the aims of science education and the global learning approach. However, it is evident that professional learning needs to make these links explicit, as well as underscore practitioners' common beliefs. It is also apparent that in order to be operationalized, the global learning approach needs to be underpinned by science subject knowledge. The interface between science subject knowledge and global learning pedagogical strategies will be paramount for its success.

Schools that trialled the approach observed a greater engagement from their students as well as improved retention of subject knowledge. More significantly, case study teachers articulated a greater motivation to research and plan authentic global links with conceptual understanding of science, which in turn developed their own awareness of global issues. Further research is needed, therefore, to see whether similar outcomes are found across a greater number of school settings, exploring how teachers and pre-service teachers can be supported in their own understanding of SDGs and global learning, with a consequent impact on primary science teaching and learning.

As all respondents were positive about the concept of global learning in primary science, and their beliefs about the purpose of primary science aligned with the global learning approach, it can be argued that being more explicit in policy (in the National Curriculum aims) would ensure that a global learning approach is not left to chance, enabling the profile of science to be elevated while operationalizing the SDGs within the subject.

\section{Notes on the contributor}

Amy Strachan is Senior Lecturer in primary science education and a doctoral student at St Mary's University, Twickenham. She worked as a primary school teacher for over 12 years, teaching and lecturing in The Gambia, Japan and the UK. She is also a lead facilitator of STEM education, providing professional development in the area of primary science education.

\section{References}

Andreotti, V. (2011) 'Relativizing Western knowledge production in spaces of dissensus: The OSDE methodology'. In V. Andreotti, Actionable Postcolonial Theory in Education. London: Palgrave Macmillan. 
Bamber, P., Bullivant, A. and Stead, D. (2013) 'Measuring attitudes towards global learning among future educators in England'. International Journal of Development Education and Global Learning, 5 (3), 5-27. Online. https://doi.org.10.18546/IJDEGL.05.3.02.

Bourn, D. (2015) The Theory and Practice of Development Education: A pedagogy for global social justice. Abingdon: Routledge.

Bourn, D. (2016) 'Global learning and the school curriculum'. Management in Education, 30 (3), 121-5. Online. https://doi.org/10.1177/0892020616653178.

Bracken, M. and Bryan, A. (2010) 'The reflective practitioner model as a means of evaluating development education practice: Post-primary teachers' self-reflections on "doing" development education'. Policy and Practice: A Development Education Review, 11, $22-41$.

Cordingley, P. (2015) A World-Class Teaching Profession: Response to the DfE consultation. London: Centre for the Use of Research and Evidence in Education (CUREE).

Creswell, J.W. and Plano Clark, V.L. (2011) Designing and Conducting Mixed Methods Research. 2nd ed. Thousand Oaks, CA: SAGE Publications.

DfE (Department for Education) (2013) National Curriculum in England: Science programmes of study. London: The Stationery Office.

Goodall, J., Day, C., Lindsay, G. and Mujis, D. (2005) 'Evaluating the Impact of Continuing Professional Development', University of Warwick. Online. https://warwick.ac.uk/fac/soc/cedar/ projects/completed05/contprofdev/cpdfinalreport05.pdf (accessed 19 August 2020)

Guskey, T.R. (2000) Evaluating Professional Development. Thousand Oaks, CA: Corwin Press.

Hunt, F. and King, R.P. (2015) Supporting Whole School Approaches to Global Learning: Focusing learning and mapping impact. Research Paper no. 13. London: Development Education Research Centre.

Imants, J. and Van der Wal, M. (2020) 'A model of teacher agency in professional development and school reform'. Journal of Curriculum Studies, 52 (1), 1-14. Online. https://doi.org/10.1080/00220 272.2019.1604809.

Lave, J. and Wenger, E. (1991) Situated Learning: Legitimate peripheral participation. Cambridge: Cambridge University Press.

Lipman, M., Sharp, A. and Oscanyan, F. (1980) Philosophy in the Classroom. Philadelphia, PA: Temple University Press.

Leonardi, S., Lamb, H., Howe, P. and Choudhoury, A. (2017) 'State of the Nation' Report of UK Primary Science Education. Leicester: CFE Research for the Wellcome Trust.

Leonardi, S., Lamb, H., Harrison, J., Stutz, A., Steer, R., Howe, P. and Corley, A. (2019) Understanding the 'State of the Nation' Report of UK Primary Science Education. Leicester: CFE Research for the Wellcome Trust.

Mezirow, J. (2000) Learning as Transformation: Critical perspectives on a theory in progress. San Francisco: Jossey-Bass Publishers.

Pajares, M.F. (1992) 'Teachers' beliefs and educational research: Cleaning up a messy construct'. Review of Educational Research, 62 (3), 307-32. Online. https://doi.org/10.3102/00346543062003307.

Priestley, M., Biesta, G.J.J. and Robinson, S. (2015) Teacher Agency: An ecological approach. London: Bloomsbury Academic.

Priestly, M., Edwards, R., Priestly, A. and Miller, K. (2012) 'Teacher agency in curriculum making: Agents of change and spaces for manoeuvre'. Curriculum Inquiry, 42 (2), 191-214. Online. https://doi.org/10.1111/j.1467-873X.2012.00588.x.

Shulman, L. (1986) 'Those who Understand: Knowledge growth in teaching'. Educational Researcher, 15 (2), 4-14.

Standards and Testing Agency (2019) Key Stage Two Science Sampling 2018. Methodology note and outcomes. London: Standards and Testing Agency.

UN (United Nations) (2015) Transforming Our World: The 2030 agenda for sustainable development. New York: United Nations.

UN (United Nations) (2017) 'Global Indicator Framework for the Sustainable Development Goals and Targets of the 2030 Agenda for Sustainable Development'. Online. https://unstats.un.org/ sdgs/indicators/Global\%20Indicator\%20Framework\%20after\%20refinement_Eng.pdf (accessed 19 August 2020).

UNECE (United Nations Economic Commission for Europe) (2016) Ten Years of the UNECE Strategy for Education for Sustainable Development. Evaluation report on the implementation of the UNECE Strategy for Education for Sustainable Development from 2005 to 2015. New York and Geneva: United Nations.

UNESCO (United Nations Educational, Scientific and Cultural Organization) (2014) Global Citizenship Education: Preparing learners for the challenges of the twenty-first century. Paris: United Nations Educational, Scientific and Cultural Organization. 